\title{
Evolution and phylogeny of the mud shrimps (Crustacea: Decapoda) revealed from complete mitochondrial genomes
}

Feng-Jiau Lin ${ }^{1 \dagger}$, Yuan Liư ${ }^{2 \dagger}$, Zhongli Sha ${ }^{2}$, Ling Ming Tsang ${ }^{3}$, Ka Hou Chu ${ }^{3}$, Tin-Yam Chan ${ }^{4}$, Ruiyu Liu ${ }^{2}$ and Zhaoxia $\mathrm{Cui}^{2^{*}}$

\begin{abstract}
Background: The evolutionary history and relationships of the mud shrimps (Crustacea: Decapoda: Gebiidea and Axiidea) are contentious, with previous attempts revealing mixed results. The mud shrimps were once classified in the infraorder Thalassinidea. Recent molecular phylogenetic analyses, however, suggest separation of the group into two individual infraorders, Gebiidea and Axiidea. Mitochondrial (mt) genome sequence and structure can be especially powerful in resolving higher systematic relationships that may offer new insights into the phylogeny of the mud shrimps and the other decapod infraorders, and test the hypothesis of dividing the mud shrimps into two infraorders.

Results: We present the complete mitochondrial genome sequences of five mud shrimps, Austinogebia edulis, Upogebia major, Thalassina kelanang (Gebiidea), Nihonotrypaea thermophilus and Neaxius glyptocercus (Axiidea). All five genomes encode a standard set of 13 protein-coding genes, two ribosomal RNA genes, 22 transfer RNA genes and a putative control region. Except for T. kelanang, mud shrimp mitochondrial genomes exhibited rearrangements and novel patterns compared to the pancrustacean ground pattern. Each of the two Gebiidea species (A. edulis and U. major) and two Axiidea species (N. glyptocercus and N. thermophiles) share unique gene order specific to their infraorders and analyses further suggest these two derived gene orders have evolved independently. Phylogenetic analyses based on the concatenated nucleotide and amino acid sequences of 13 protein-coding genes indicate the possible polyphyly of mud shrimps, supporting the division of the group into two infraorders. However, the infraordinal relationships among the Gebiidea and Axiidea, and other reptants are poorly resolved. The inclusion of mt genome from more taxa, in particular the reptant infraorders Polychelida and Glypheidea is required in further analysis.

Conclusions: Phylogenetic analyses on the mt genome sequences and the distinct gene orders provide further evidences for the divergence between the two mud shrimp infraorders, Gebiidea and Axiidea, corroborating previous molecular phylogeny and justifying their infraordinal status. Mitochondrial genome sequences appear to be promising markers for resolving phylogenetic issues concerning decapod crustaceans that warrant further investigations and our present study has also provided further information concerning the mt genome evolution of the Decapoda.
\end{abstract}

Keywords: Mud shrimps, Mitochondrial genome, Gene order, Evolution, Phylogenetics

\footnotetext{
*Correspondence: zhxcui@qdio.ac.cn

'Equal contributors

${ }^{2}$ EMBL, Institute of Oceanology, Chinese Academy of Sciences, Qingdao

266071, China

Full list of author information is available at the end of the article
} 


\section{Background}

Decapoda is one of the most diverse groups of crustaceans, with over 15,000 extant species in 180 families [1]. Seven main groups (with the ranks of sub- or infraorder) are generally recognized in Decapoda. They are Dendrobranchiata (e.g. penaeoid shrimps and allies), Caridea (caridean shrimps), Stenopodidea (stenopodid shrimps), lobsters (Macrura Reptantia), mud shrimps or ghost shrimps (Thalassinidea or Gebiidea + Axiidea), Anomura (hermit crabs and allies) and Brachyura (true crabs). The phylogenetic relationships amongst these groups within the Decapoda and even the monophyletic status of these groups have long been debated amongst carcinologists and general consensus has yet to be reached, with recent morphological cladistic and molecular analyses still showing contrasting results (Figure 1). One the most controversial recent findings is that the mud shrimps are not monophyletic [1-8], with some of them representing the sister taxon of the other Reptantia (= non-shrimp like decapod crustaceans).

Mud shrimps have a worldwide distribution from shallow to deep waters, and more than 600 extant species have been described to date [1]. The classification scheme of mud shrimps have been in flux at all levels. They are often considered to be a monophyletic group up to the rank of infraorder, i.e., Thalassinidea [9-16]. According to different authors, these animals have been treated under Anomura [17-21], as an independent group within the Reptantia [10,11,14,22,23], or aligned with the lobsters [24]. While some authors [25-29] had long questioned the monophyly of Thalassinidea and divided it into two groups (namely Gebiidea and Axiidea), the monophyly of Thalassinidea has been supported by some morphological cladistic analyses $[9,10,12,14,16]$, molecular data $[11,30]$ or combined morphological and molecular analysis [15]. Nevertheless, the latest molecular analyses [3-8] mostly concur in the separation of Thalassinidea.

In most molecular analyses, partial DNA sequences are used to resolve the phylogenetic relationships of decapod crustaceans $[3,11,15,22,31-34]$, but they are often too short to contain a sufficient amount of genetic variation for resolving higher systematics $[5,35]$. In the previous studies involving mud shrimps $[3,4,6,7,11,15,30]$, the total length of partial sequences used is less than $5300 \mathrm{bp}$. The animal mitochondrial (mt) DNA is a small, extrachromosomal, and circular double-stranded DNA molecule of 12-20 kb in size, and usually contains the same set of 37 genes, including 13 protein-coding genes, two ribosomal RNA genes and 22 transfer RNA genes [36-38]. Recent advances in DNA sequencing technology have allowed rapid, costeffective sequencing of the complete mtDNA genome. And it has become increasingly popular in studies of molecular evolution, phylogeography, and phylogenetic relationships

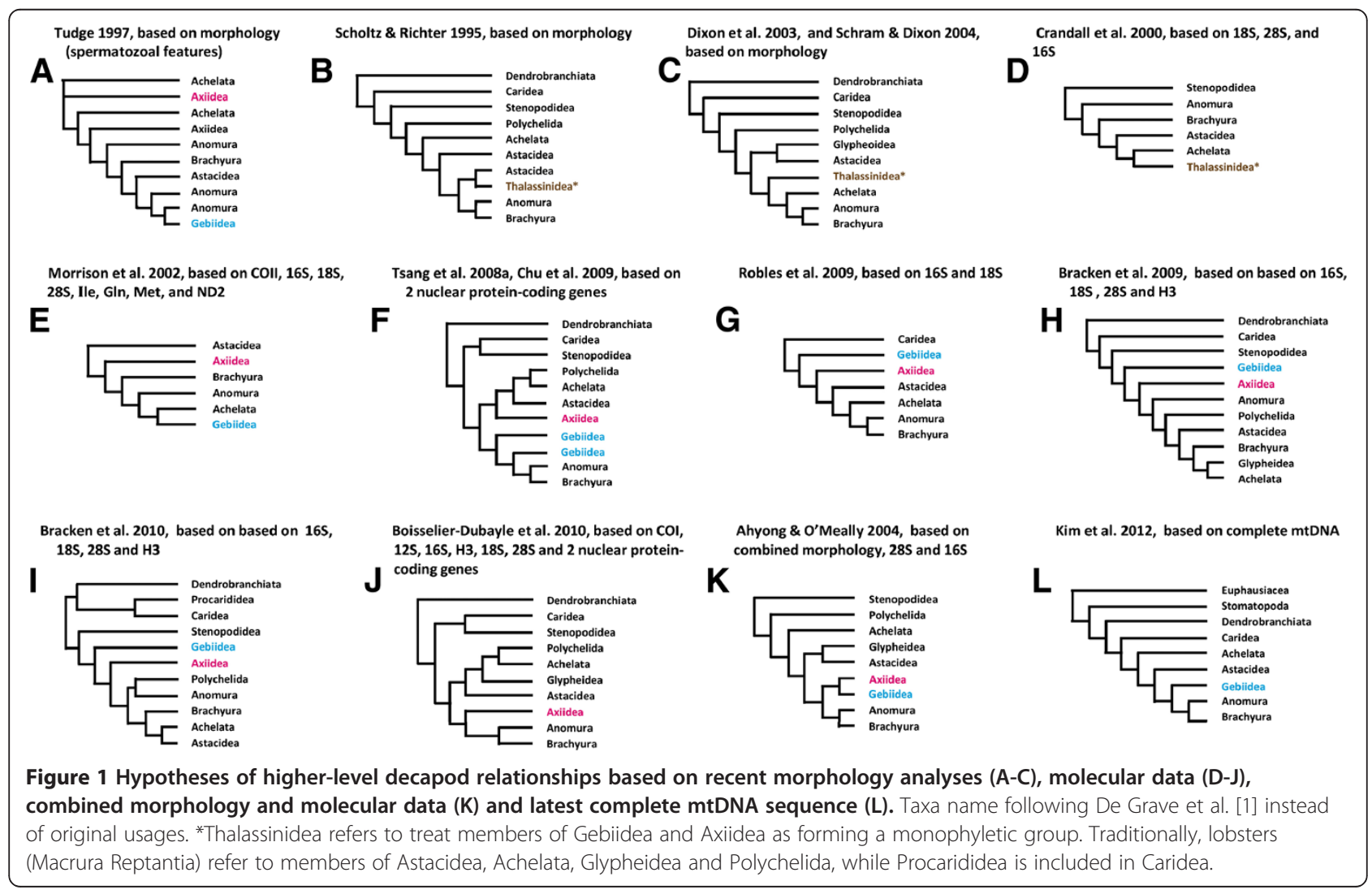


at various taxonomic levels [38-43], mainly because of its maternal inheritance, the presence of strictly orthologous genes evolving at different rates, and lack of genetic recombination [38,44-46]. Complete mtDNA sequences provide sets of genome-level characteristics, such as gene rearrangement, which is rather conserved within some major metazoan lineages, and therefore can be especially powerful in resolving systematic relationships among higher taxa [3,40,42,47-49].

Complete mitochondrial genome sequences are now available for 37 decapod crustaceans (April, 2012; http:// www.ncbi.nlm.nih.gov, with a sergesteid species Actetes chinensis with mitogenome reported [50] but not yet available from GenBank) that represent all the main groups. However, the latest phylogenetic reconstruction of decapod crustaceans using complete mitochondrial genome sequences $[51,52]$ still has low resolution in most of the deep branches, notably with the status of Stenopodidea, lobsters and mud shrimps unresolved. Moreover, only a single species of mud shrimp collected from Korea, namely Upogebia major (De Haan, 1841) belonged to Gebiidea, has been sequenced for mitochondrial genome [53].

In this paper, we report the complete mitochondrial genomes of five thalassinidean species with representatives from both Gebiidea and Axiidea. They are Austinogebia edulis (Ngoc-Ho and Chan 1992), Upogebia major (from China) and Thalassina kelanang Moh and Chong, 2009 of Gebiidea, and Nihonotrypaea thermophilus Lin, Komai and Chan, 2007 and Neaxius glyptocercus (Von Martens, 1868) of Axiidea. Considering the difference in sampling location and sequence variation, we only included the mitochondrial genome of Upogebia major we sequenced in the analysis. The mitochondrial genome structure of these five mud shrimps were compared with those of other decapods. The gene rearrangement occurred in mud shrimps were identified. Moreover, the infraorder status of Axiidea and Gebiidea was analyzed based on all 50 malacostracan mitochondrial genomes currently available.

\section{Results}

\section{Genome composition}

The complete mtDNA sequences of $A$. edulis, $U$. major, T. kelanang, N. glyptocercus and $N$. thermophilus were determined to be 15,761, 16,143, 15,528, 14,909 and $15,240 \mathrm{bp}$ long, respectively (Additional file 1). They all contained 13 protein-coding genes (PCGs), two ribosomal RNA genes (rRNA), 22 transfer RNA genes (tRNA) and a putative control region as in other metazoans (Figure 2; Additional files 2, 3, 4, 5, 6). The structural organizations of the five mitochondrial genomes are shown in Figure 2.

The overall $\mathrm{A}+\mathrm{T}$ content of $A$. edulis mtDNA is $73.6 \%$, higher than that of other decapod species except Scylla tranquebarica (73.8\%) (see Additional file 1). The overall A + T content of U. major, T. kelanang, N. glyptocercus and $N$. thermophilus ranged from 66.3-70.7\%, similar to other decapods (see Additional file 1). This pattern of base composition in five mud shrimps held for the protein-coding, rRNA, tRNA genes, and the control region when considered separately.

For the 13 PCGs of five mitochondrial genomes, nine protein-coding genes (atp6, atp8, cox1, cox2, cox3, cob, nad2, nad3, and nad6) were encoded on the H-strand, while the remaining four (nad1, nad4, nad4L, and nad5) were encoded on the L-strand (Additional files 2, 3 4, 5, 6). This transcriptional polarity is identical in all reported decapod mitochondrial genomes. Moreover, they all contained two reading frames overlapped on the same strand: atp6 and atp8, nad4 and nad4L each
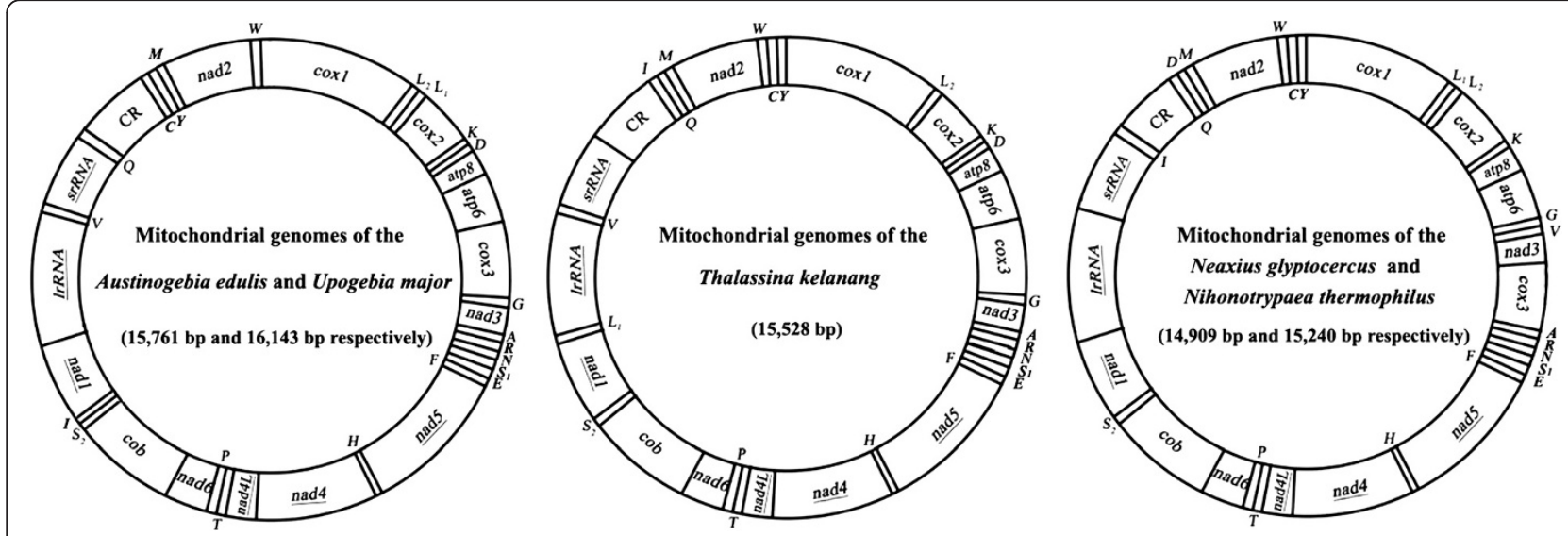

Figure 2 Gene maps of the mitochondrial genomes of Austinogebia edulis, Upogebia major, Thalassina kelanang, Neaxius glyptocercus and Nihonotrypaea thermophilus. Genes encoded on the heavy or light strands are shown outside or inside the circular gene map, respectively. The putative control region is denoted by "CR". The tRNA genes are designated by single-letter amino acid codes except those encoding leucine and serine, $L_{1}, L_{2}, S_{1}$ and $S_{2}$ denote $t R N A^{\operatorname{Leu}(C U N)}, t R N A^{\operatorname{Leu}(U U R)}, t R N A^{\operatorname{Ser}(A G N)}$, and $t R N A^{\operatorname{Ser}(U C N)}$ genes, respectively. 
shared seven nucleotides. No notable reduction or extension of gene length as compared to other decapods was observed.

In A. edulis, $U$. major and T. kelanang mitochondrial genomes, $\operatorname{lr} R N A$ and $\operatorname{sr} R N A$ were separated by $t R N A^{\text {Val }}$, while the two rRNA genes in $N$. glyptocercus and $N$. thermophilus mtDNA were adjacent to each other (Figure 2). The rRNAs were both coded on L-strand. All five mitochondrial genomes had typical 22 tRNA genes, which ranged from 61 to $73 \mathrm{bp}$ in length (Additional files $2,34,5,6$ ), and all of them (except $t R N A^{\operatorname{Ser}(A G N)}$ ) formed a typical cloverleaf secondary structure. The $t R N A^{\operatorname{Ser}(A G N)}$ lacked DHC arm, a feature commonly observed in metazoan mtDNAs [54].

The non-coding regions of A. edulis, U. major, T. kelanang, $N$. glyptocercus and $N$. thermophilus mtDNAs were $845,1,188,784,162,581 \mathrm{bp}$, respectively (see Additional files 2, $34,5,6$ ). Of these regions, the largest non-coding region in each genome was assumed to be the control region $(\mathrm{CR})$ with high $\mathrm{A}+\mathrm{T}$ composition (Additional file 1). The mtDNA of $N$. glyptocercus had the shortest CR (91 bp) among decapods, and its A + T content was the lowest (59.3\%) (Additional file 1). The remaining non-coding regions of the five mitochondrial genomes were considered to be intergenic spacers. Most intergenic spacers contained a few nucleotides (1-56 bp) (Additional file 2, 34 , 5, 6). However, a relatively large spacer, 177 bp in length, was found between srRNA and $t R N A^{G l}$ in the $U$. major mtDNA (Figure 2 and Additional file 3). Further analyses showed that this large region had an $\mathrm{A}+\mathrm{T}$ content of $89.8 \%$, higher than that in control region $(85.2 \%)$.

\section{Gene order}

The complete genome arrangements of five mud shrimps were depicted in Figures 3 and 4. The gene order of T. kelanang mtDNA was identical to that of the pancrustacean (Crustacea + Hexapoda) ground pattern [55], while the genomic organization of four other mud shrimps showed two novel gene orders compared to other $\mathrm{mt}$ genomes in the MitoZoa database. Specifically, the mitochondrial genomes of A. edulis and U. major, and $N$. glyptocercus and $N$. thermophilus, shared the same gene order, respectively.

Compared with the pancrustacean ground pattern, at least five genes were rearranged in each of the mt genome of A. edulis, U. major, N. glyptocercus and N. thermophilus (Figures 3 and 4). The $t R N A^{\operatorname{Leu}(C U N)}\left(L_{1}\right)$, located between nad1 and IrRNA in other arthropod mtDNAs, was found between $t R N A^{\operatorname{Leu}(U U R)}\left(L_{2}\right)$ and $\operatorname{cox} 2$ in $A$. edulis and $U$. major, and between $\operatorname{cox} 1$ and $t R N A^{\operatorname{Leu}(U U R)}\left(L_{1}\right)$ in N. glyptocercus and N. thermophilus. The $t R N A^{\text {Ile }}(I)$ was located between $t R N A^{\operatorname{Ser}(U C N)}$ $\left(S_{2}\right)$ and nad1 in A. edulis and $U$. major, and between
srRNA and CR in N. glyptocercus and N. thermophilus. In A. edulis and $U$. major, $t R N A^{G l n}(Q)$ moved upstream to the putative control region, and $t R N A^{C y s}(C)$ and $t R N A^{T y r}(Y)$ moved to the location between $\mathrm{CR}$ and $t R N A^{\text {Met }}(M)$. Additionally, in N. glyptocercus and N. thermophilus mtDNAs, the tRNA gene tRNA $A^{\text {Val }}(V)$ changed to downstream of $t R N A^{G l y}(G), t R N A^{A s p}(D)$ moved to upstream of $t R N A^{\text {Met }}(M)$, and only one protein-coding gene cox3 was involved in the rearrangement. The cox3 located between atp6 and $t R N A^{G l y}(G)$ in other crustaceans moved upstream to $t R N A^{\text {Ala }}(A)$ in $N$. glyptocercus and $N$. thermophilus. All these genes rearranged in the same orientation as the mitochondrial gene arrangement of pancrustacean ground pattern with the exception of $t R N A^{\operatorname{Leu}(C U N)}\left(L_{1}\right)$ in the four mud shrimps, and $t R N A^{\text {Ile }}(I)$ and $t R N A^{\text {Val }}(V)$ in N. glyptocercus and $N$. thermophilus. Noticeably, the two tRNA ${ }^{\text {Leu }}$ sequences in each mt genome of the four mud shrimps shared significant identity with each other, and the similarity was $86 \%$ in A. edulis, $80 \%$ in $U$. major, $77 \%$ in N. glyptocercus and $93 \%$ in N. thermophilus.

\section{Phylogenetic analysis}

The concatenated alignments of nucleotide and amino acid data from all 13 protein-coding genes were used to investigate the phylogenetic relationships among major lineages of Decapoda. For each dataset, the BI and ML analyses generated nearly identical tree topology except for two branches denoted by open arrowheads, which strongly supported the monophyly of Decapoda (Figure 5A and B). Values of nodal support were typically congruent between the two trees. Both the nucleotide and amino acid phylogenies indicated strong support $(\mathrm{BPP} / \mathrm{ML}$ bootstrap value in nucleotide phylogeny $=0.99 / 93, \mathrm{BPP} / \mathrm{ML}$ bootstrap value in amino acid phylogeny $=0.99 / 74$ ) for the separation of two suborders Dendrobranchiata and Pleocyemata in Decapoda. The placing of Caridea at the base of Pleocyemata was well supported $(0.80 / 93,0.99 / 69)$. The remaining natant decapod Stenopodidea was sister with Reptantia with a strong support in amino acid phylogeny (BPP/ML bootstrap value $=0.98 / 79$ ) but only moderate support in nucleotide phylogeny (BPP $=0.70)$. Reptantia was strongly supported to be a monophyletic group (0.99/ $100,1.00 / 100)$.

Within Repantia, the Brachyura and Anomura (i.e. Mieura) were reciprocally monophyletic $(0.99 / 100,1.00 /$ $100)$, and their sister relationship also received supported $(0.71 / 85,99 / 61)$. The monophyly of Thalassinidea (Gebiidea + Axiidea) was not supported in the nucleotide phylogeny or the amino acid phylogeny. Yet AU test could not reject monophyly of Thalassinidea. Gebiidea and Axiidea were both shown to be well supported clades $(0.99 / 100,1.00 / 100)$, with moderate support 


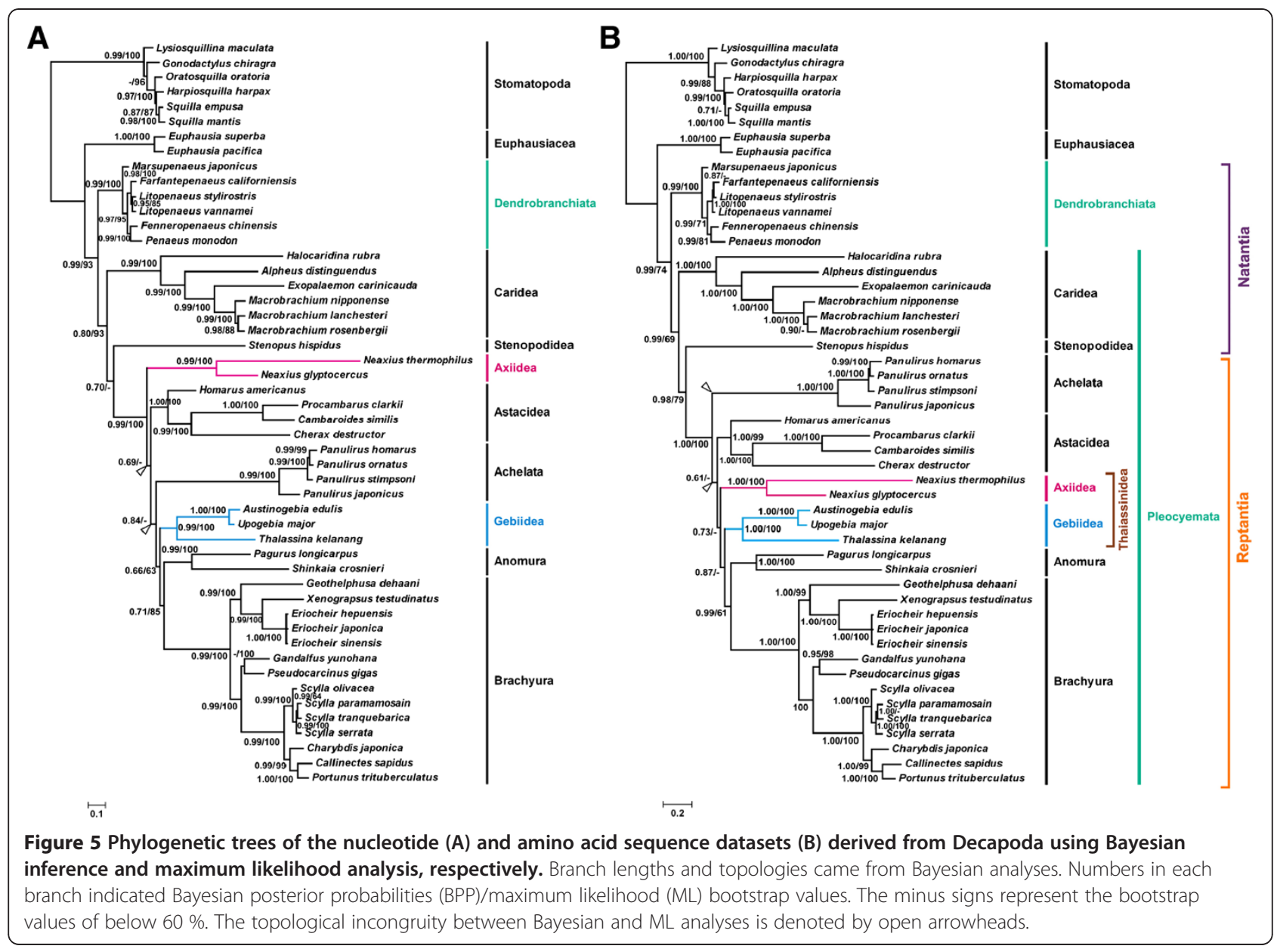

$(0.66 / 63,0.87 /-)$ for the sister relationship between Gebiidea and Mieura. However, the position of Axiidea in Reptantia was incongruent between the nucleotide and amino acid trees. Similarly, there was no support for the monophyly of the lobsters (Achelata + Astacidea).

\section{Discussion}

\section{Molecular features of mitochondrial genomes in mud} shrimps

Features of decapod mitochondrial genomes include a high $\mathrm{A}+\mathrm{T}$ content and rearranged gene structure [5658]. These features are also apparent in the complete mtDNA sequences of four of the mud shrimps studied, i.e., A. edulis, U. major, N. glyptocercus and N. thermophilus. Together with $T$. kelanang mtDNA, all five mitochondrial genomes have the same gene number as other pancrustaceans (13 PCGs, 2 rRNAs, 22 tRNAs). However, the $U$. major mtDNA annotated by Kim et al. [53] has an extra $t R N A^{\operatorname{Leu}(C U N)}$ between nad1 and $\operatorname{lr} R N A$. The different annotation is due to amphibolous beginning of $\operatorname{lrRNA}$ and identification of $t R N A^{\operatorname{Leu}(C U N)}$. No anticodon and tRNA-like secondary structure of $t R N A^{\operatorname{Leu}(C U N)}$ is identified between nad1 and $\operatorname{lr} R N A$ in the $U$. major
mtDNA we sequenced, as in the one sequenced by Kim et al. [53].

Most variations in size in mitochondrial genomes are caused by sequences in non-coding regions [53,58]. $N$. glyptocercus mtDNA has the shortest control region among the decapod mtDNA published, while in $U$. major mtDNA, a relative large intergetic spacer (177 bp) with high $\mathrm{A}+\mathrm{T}$ content is discovered. Such a large ATrich region other than $C R$ rarely occurs in malacostracan species and has only been reported in the stomatopods Oratosquilla oratoria [59] and Squilla mantis [60]. But the length and position of the second AT-rich region are different among the above three species. Moreover, such an AT-rich region is notably absent in the other four mud shrimps, indicating that it is not a conserved feature of thalassinidean mtDNA.

The pancrustacean ground pattern is well retained in T. kelanang mitogenome, suggesting that the ancestor of mud shrimps (or at least the Gebiidea) had a typical pancrustacean mtDNA gene order. However, the other four mud shrimps, A. edulis, U. major, N. glyptocercus and $N$. thermophilus have rearranged mitochondrial genomes compared to the pancrustacean ground pattern 
(Figure 3) $[56,57,61,62]$. Further searches in the MitoZoa database show that mitochondrial sequences of $A$. edulis and $U$. major, N. glyptocercus and $N$. thermophilus exhibit two novel genome structures, respectively. Except for $t R N A^{\operatorname{Leu}(C U N)}$, the rearranged genes of A. edulis and $U$. major belonged to Gebiidea occur at $t R N A^{I l e}-t R N A^{T y r}$ junction. However, the rearranged genes of the two axiids $N$. glyptocercus and $N$. thermophilus occur more dispersedly.

\section{Possible mechanisms for gene rearrangement}

Two major categories of mechanisms have been suggested to explain mitochondrial gene rearrangement: (1) tandem duplication followed by random or non-random deletion $[63,64]$, and (2) non-homologous recombination $[65,66]$. The first mechanism may explain many or most of the observed rearrangements, while the second one has been proposed to explain gene translocation and inversion [56,67]. Combined the above mechanisms and the results from CREx (Additional files 7 and 8), the rearrangement of four mud shrimps mtDNAs can be depicted as three or four steps (Figures 3 and 4).

For $A$. edulis and $U$. major mtDNA, firstly, transposition of $t R N A^{\text {Ile }}(I), t R N A^{\text {Cys }}(C)$ and $t R N A^{T y r}(Y)$ occurred before duplication. If this event occurred after duplication, more genes were duplicated and longer distance translocation were required (Figure 3A). Secondly, an independent duplication/random loss events occurred to account for the translocation of $t R N A^{G l n}(Q)$ (Figure 3B). Thirdly, a duplication/anticodon mutation/non-random loss event $[52,68]$ is expected to account for translocation of tRNA $A^{\operatorname{Leu}(C U N)}\left(L_{1}\right)$ (Figure $3 C$ ). A duplication of $t R N A^{\operatorname{Leu}(U U R)}$ $\left(L_{2}\right)$ on $\mathrm{H}$-strand might have happened. One of the duplicated $t R N A^{\operatorname{Leu}(U U R)}\left(L_{2}\right)$ changed into $t R N A^{\operatorname{Leu}(C U N)}\left(L_{1}\right)$ by anticodon mutation. Subsequently the ancestral $t R N A^{\operatorname{Leu}(C U N)}\left(L_{1}\right)$ lost the function and eventually is deleted from L-strand.

For N. glyptocercus and N. thermophilus mtDNA, transposition of $t R N A^{\text {Ile }}$ (I) occurred first followed by one recombination event (Figure $4 \mathrm{~A}$ ). Then an independent duplication/random loss event occurred to account for the translocation of $\operatorname{cox} 3$ (Figure 4B). This was followed by transposition of $t R N A^{A s p}$ (D) and $t R N A^{\text {Val }}$ $(V)$ and a recombination event (Figure 4C). Finally, a duplication/anticodon mutation/non-random loss event $[52,68]$ occurred to account for the translocation of $t R N A^{\operatorname{Leu}(C U N)}\left(L_{1}\right)$ (Figure 4D).

Another possibility for the translocation of $t R N A^{\operatorname{Leu}(C U N)}$ $\left(L_{1}\right)$ predicted by CREx is based on "duplication/random loss model" [63]. This interpretation seems less likely given that there is a long distance between $\operatorname{tRNA} A^{\operatorname{Leu}(U U R)}\left(L_{2}\right)$ and $t R N A^{\operatorname{Leu}(C U N)}\left(L_{1}\right)$ in the ancient arrangement, as well as the presence of inversion in $\operatorname{tRNA} A^{\operatorname{Leu}(\mathrm{CUN})}\left(L_{1}\right)$ [52]. Moreover, the sequence homology between $t R N A^{\text {Leu(UUR) }}$
$\left(L_{2}\right)$ and $t R N A^{\operatorname{Leu}(C U N)}\left(L_{1}\right)$ in A. edulis, U. major, N. glyptocercus and $N$. thermophilus is higher than any two other randomly chosen $t R N A$ s. It seems to be more possible that two $t R N A^{\text {Leu }}$ arose from duplication followed by anticodon mutation. The similar duplication/anticodon mutation events have also been reported in other crustaceans, for example in amphipods Caprella scaura [69] and Gammarus duebeni [70], and decapods Geothelphusa dehaani [71] and Stenopus hispidus [52].

Under the above models, including the random and nonrandom loss, incomplete deletion or partial retention of duplication resulted in the formation of the multiple intergenic spacers (Additional files 2, 34 , 5, 6). These results indicate that intergenic spacers might serve as a guide in deducing the generation of gene rearrangement [56]. Moreover, the distinct rearrangement processes suggest that Gebiidea and Axiidea evolved independently from the pancrustacean ground pattern.

\section{Phylogenetic relationships of the major clades in Decapoda}

With higher taxon samplings and the inclusion of all the major groups of decapod crustaceans, the present complete mitochondrial genomic analysis strongly supports that the Caridea is sister to the other Pleocyemata. Similar to the results of Shi et al. [52], Stenopodidae is revealed to be a sister clade of Reptantia. While this relationship is only weakly supported in Shi et al. [52], this grouping is strongly supported in our tree based on amino acid sequences.

Within the Reptantia, the sister relationship between Brachyura and Anomura (i.e. the Meiura) has always received very high support in complete mitochondrial genomic analyses $[51,52,62]$. The present result suggests that Gebiidea is the sister group of Meiura though only with moderate support. In general, the topology of the currently most extensive complete mitochondrial genomic tree of decapod crustaceans (particularly the one based on amino acid sequences) is most similar to the most recent $\mathrm{mt}$ genome analyses by Kim, Park, et al. [51], and those of Scholtz and Richter [10] and Ahyong and O'Meally [15] deduced from morphology and combined morphology and molecular (16S and 28S) data, respectively. The trees of Scholtz and Richter [10] and Ahyong and O'Meally [15] are essentially the same except for the identity of the sister clade of Thalassinidea (i.e. Gebiidea + Axiidea), which is considered to be monophyletic. Thalassinidea is sister to Mieura in Ahyong and O'Meally [15] but in Scholtz and Richter [10] it is sister to the clawed lobster Astacidea which is shown to be polyphyletic. The main difference between the present result with these two analyses is that Gebiidea and Axiidea do not make up a monophyletic group while the position of Astacidea is unresolved. The 
mitogenome tree of Kim et al. [50] includes only one mud shrimp species belonged to Gebiidea. Adding two more species and genera of Gebiidea in the present work reveals a similar topology of Gebiidea being sister to Mieura. However, the other mud shrimp group Axiidea does not cluster with Gebiidea.

As the results of complete mitochondrial genome sequence analysis are now rather consistent with the conclusions deduced from some morphology and partial gene sequence data, it seems to be promising in using complete mtDNA sequence to reconstruct the evolutionary history of decapod crustaceans. Nevertheless, more taxon sampling, particularly the inclusion of certain key groups such as the sergesteid shrimp (supposed to be sister to Penaeoidea in Dendrobranchiata), blind lobsters Polychelida [4], primitive cave shrimp Procarididea [7], the living fossil lobster Glypheidea [23], the enigmatic shrimp Luciferidae [72] and the various bizarre anomuran groups [73], will be necessary to achieve this goal.

\section{Conclusions}

This study presents five complete mitochondrial genomes of mud shrimps, Austinogebia edulis, Upogebia major and Thalassina kelanang of Gebiidea, and Nihonotrypaea thermophilus and Neaxius glyptocercus of Axiidea. The contents of individual $\mathrm{mt}$ genes in these five mud shrimps are similar to that in other decapods. The $U$. major mt genome contain a relative large intergenic spacer with higher $\mathrm{A}+\mathrm{T}$ content than that in control region. The $N$. glyptocercus mt genome, the shortest decapod mtDNA known, has the shortest control region. Except for T. kelanang, the other four mud shrimps have rearranged $\mathrm{mt}$ genomes compared to pancrustacean ground pattern. A duplication/loss (random and nonran$\mathrm{dom}$ ) and recombination model may result in their $\mathrm{mt}$ gene order. The different gene arrangement process suggests the derived gene orders of Gebiidea and Axiidea might have evolved independently. Phylogenetic analyses do not support the monophyly of mud shrimps, while the positions of Gebiidea and Axiidea in Reptantia are poorly resolved.

\section{Methods}

\section{Sample collection and DNA extraction}

The collecting sites of the mud shrimp specimens used in the present study are A. edulis from Starfish Bay, Hong Kong, $U$. major from Qingdao No.1 Bathing Beach, China, T. kelanang from Kelanang Beach, Selangor, Malaysia, N. glyptocercus from Kenting, Taiwan and $N$. thermophilus from Kueishan Island, Taiwan. The specimens obtained were stored in 75-95\% ethanol. Total genomic DNA for all species was extracted from tissues by using a DNeasy tissue kit (Qiagen) following the manufacturer's protocol.

\section{PCR and sequence determination of $A$. edulis and $U$. major mitochondrial genomes}

Four short fragments of the genes cox1, nad5, $\operatorname{lr} R N A$ and $c o b$ were first determined by PCR with the universal primer sets of LCO1490/HCO2198 [74], nad5F/nad5R [75], 16S1471/16S1472 [76] and cobF424/ cobR876 [77]. PCR products were purified using the Qiaquick Gel extraction Kit (Qiagen) and directly sequenced with ABI 3730xl DNA Analyzer.

Based on the sequences obtained above, long PCR primers were designed to amplify the entire A. edulis (AE) and $U$. major (UM) mitochondrial genomes in four fragments: AE/UMcox1F-AE/UMnad5R, AE/UMnad5F-AE/ UMcobR, and AE/UMcobF-AE/UM16SR, AE/UM16SRAE/UMcox1R, with the PCR products of approximate $5.5 \mathrm{~kb}, 3.7 \mathrm{~kb}, 1.9$ and $4.5 \mathrm{~kb}$ in length, respectively (Additional file 9). PCR reactions were carried out in $25 \mu \mathrm{l}$ reaction mixtures containing $18.8 \mu \mathrm{l}$ of sterile distilled $\mathrm{H}_{2} \mathrm{O}, 2.5 \mu \mathrm{l}$ of $10 \times$ LA PCR buffer II $\left(\mathrm{Mg}^{2+}\right.$ plus, Takara), $0.5 \mu \mathrm{l}$ of dNTP (10 mM each), $1 \mu \mathrm{l}$ of each primer $(5 \mu \mathrm{M}), 0.2 \mu \mathrm{l}$ of LA Taq polymerase (5 unit/ $\mu \mathrm{l}$, Takara), and $1 \mu$ l of DNA template (approximate $30 \mathrm{ng}$ ). The amplifications were performed on TaKaRa PCR Thermal Cycler Dice Model TP600 (Takara Bio Inc.) with an initial denaturation at $94^{\circ}$ for $3 \mathrm{~min}$, followed by 34 cycles of denaturation at $94^{\circ}$ for $20 \mathrm{~s}$, annealing at $50-52^{\circ}$ for $50 \mathrm{~s}$, extension at $68^{\circ}$ for for $1 \mathrm{~min} / \mathrm{kb}$, and a final extension at $68^{\circ}$ for $10 \mathrm{~min}$. Long PCR products were purified using the Qiaquick Gel extraction Kit (Qiagen) and bidirectionally sequenced using a primerwalking strategy on ABI 3730xl DNA Analyzer.

\section{PCR and sequence determination of $T$. kelanang, $N$.} glyptocercus and $N$. thermophilus mitochondrial genomes Four partial fragments of the genes cob, cox1-cox2 (2 kb), cox3, srRNA were first determined by PCR with the primer sets of Cyb1/Cyb2 [78] crust-cox1f [79]/CCO2Rv1 [80], Scox3-F(GCCCCTTCAGTNGAAATTGG)/Scox3-R (ACTA CATCDACRAAATGTCAATATCA), and $s r R N A-F$ (AAAT TTAATTCAACATCGAGGTCGCAAACT)/srRNA-R (TT GACYGTGCRAAGGTAGCATAATAATTAG). Additional three partial mitochondrial sequences (nad4, nad5 and 12S) of $T$. kelanang were also determined with PCR primer sets of L11424-ND4/H11534-ND4M [81], crust-nd5f/crust-nd5r and crust-12Sf/crust-12Sr [79].

Based on the sequences obtained above, long PCR primers were designed to amplify the entire T. kelanang (TK), N. glyptocercus (NG) and N. thermophilus (NT) mitochondrial genomes in several fragments: TKbs-R/ H11534-ND4M [81], TKc1s-R/TK12s-R, TKc2s-F/ TKd5s-R, NGbs-F/NGrRs-R, NGc3s-F/NGbs-R, NGc1s- 
R/NGrRs-F, NGc2s-F/NGc2s-R, NTbs-R/NTc2s-F, and NTc1s-R/NTrRs-F, with the PCR products of approximate $2 \mathrm{~kb}, 3.7 \mathrm{~kb}, 3.7 \mathrm{~kb}, 2.3 \mathrm{~kb}, 5.6 \mathrm{~kb}, 3.6 \mathrm{~kb}, 2.5 \mathrm{~kb}$, $7.5 \mathrm{~kb}$ and $4.2 \mathrm{~kb}$ in length, respectively (Additional file 10). PCR reaction and sequencing were generally the same as described in $A$. edulis and $U$. major mitochondrial genomes.

\section{Sequence analysis}

Base calling was processed using Phred [82,83] and sequence reads were assembled using Phrap with default parameters. All assembled sequences were manually checked using CONSED to remove misassembles [84].

The locations of 13 protein-coding genes and two rRNAs were initially identified by DOGMA [85] with default settings, and refined by alignment with mitochondrial genomes of Panulirus japonicus (NC_004251) and Squilla mantis (NC_006081). A majority of tRNA genes was identified by the tRNAscan-SE 1.21 [86] in default search mode using mitochondrial/chloroplast DNA as the source and invertebrate mitochondrial genetic code for tRNA structure prediction. The remaining tRNA genes were identified by inspecting sequences for tRNA-like secondary structures and anticodons. The complete mtDNA sequences of A. edulis, U. major, T. kelanang, N. glyptocercus and N. thermophilus were deposited with GenBank under accession numbers JN897376-JN897380, respectively.

The inferred mitochondrial gene orders of the above five mud shrimps were compared with that of the 527 other arthropod species included in the MitoZoa database [87] (http://mi.caspur.it/mitozoa/index.php, Release 10, 14-Dec-2011). The genome rearrangement steps were predicted by algorithms implanted in CREx server [88] together with gene rearrangement models reported in previous arthropod mitochondrial genomes [56].

\section{Phylogenetic analysis}

Along with the complete mtDNA sequences from $A$. edulis, U. major, T. kelanang, N. glyptocercus and N. thermophilus, all currently available 37 decapod complete mitochondrial sequences (see Additional file 1) were used in phylogenetic analysis. The six stomatopods Gonodactylus chiragra (GenBank accession number: NC_007442), Harpiosquilla harpax (NC_006916), Lysiosquilla harpax (NC_007443), Oratosquilla oratoria (NC_014342), Squilla empusa (NC_007444) and Squilla mantis (NC_006081), and two euphausians Euphausia pacifica (NC_016184) and Euphausia superba (EU583500) served as outgroups. Both nucleotides and amino acids of 13 protein-coding genes were subjected to concatenated alignments using ClustalX 1.83 with the default settings [89]. For the nucleotides, we omitted the third codon position before alignment, according to the result of a saturation analysis [90] by DAMBE version 5.0.32 [91]. The final nucleotide and amino acid datasets consisted of 7,577 and 3,781 sites, respectively. Phylogenetic trees were built by two approaches including Bayesian inference (BI) analysis using Phylobayes 3.3b [92] and maximum-likelihood (ML) analysis using RaxML 7.0.4 [93].

For the nucleotide dataset, the model GTR + I + G was selected by JMODELTEST 0.1.1 [94]. The model MtRev + $\mathrm{I}+\mathrm{G}+\mathrm{F}$ was chosen as the best-fit model for the amino acid dataset by ProtTest version 2.4 [95]. According to preliminary analysis, the categories model with GTR (CAT-GTR) and CAT-Poisson models $[96,97]$ fit the data best and were used for BI and ML analysis of the nucleotide and amino acid data, respectively. For BI analysis, two independent MCMC chains were run simultaneously to determine whether the searching reached stabilization, and were stopped when all chains converged (maxdiff less than 0.1 ). For ML analysis, 1000 bootstraps were used to estimate the node reliability. Topology testing was performed using Consel [98] for the approximately unbiased (AU) test [99].

\section{Additional files}

Additional file 1: Genomic characteristics of decapod mitochondrial genomes.

Additional file 2: Location of genes in the mitochondrial genome of Austinogebia edulis.

Additional file 3: Location of genes in the mitochondrial genome of Upogebia major.

Additional file 4: Location of genes in the mitochondrial genome of Thalassina kelanang.

Additional file 5: Location of genes in the mitochondrial genome of Neaxius glyptocercus.

Additional file 6: Location of genes in the mitochondrial genome of Nihonotrypaea thermophilus.

Additional file 7: Mitochondrial gene order rearrangement scenario of Austinogebia edulis, Upogebia major (Decapoda: Gebiidea) inferred by CREx. The elements in the blue shaded boxes are lost in the second copy, therefore the remaining copies are moved to the front. The elements in the red shaded boxes are lost in the first copy, therefore the remaining copies are moved to the back.

Additional file 8: Mitochondrial gene order rearrangement scenario of Neaxius glyptocercus and Nihonotrypaea thermophilus (Decapoda: Axiidea) inferred by CREx. The elements in the blue shaded boxes are lost in the second copy, therefore the remaining copies are moved to the front. The elements in the red shaded boxes are lost in the first copy, therefore the remaining copies are moved to the back.

Additional file 9: Specific primers used in amplification of Austinogebia edulis and Upogebia major mitochondrial genomes.

Additional file 10: Specific primers used to amplification of the fragments which covered the gaps after sequencing Thalassina kelanang, Neaxius glyptocercus and Nihonotrypaea thermophilus mitochondrial genomes.

\section{Abbreviations}

atp6 and 8: ATPase subunit 6 and 8; bp: Base pair (s); BI: Bayesian inference; BP: Bootstrap; cox1-3: Cytochrome c oxidase subunits I-III; cob: Cytochrome b; IrRNA: 165 ribosomal RNA; ML: Maximum likelihood; Mt: Mitochondrial; mtDNA: Mitochondrial DNA; nt: Nucleotide (s); nad1-6 and $4 \mathrm{~L}: \mathrm{NADH}$ dehydrogenase subunits $1-6$ and 4 L; ORF: Open reading frame; PCG: Protein 
coding gene; PCR: Polymerase chain reaction; BPP: Bayesian posterior probabilities; rRNA: Ribosomal RNA; srRNA: $12 S$ ribosomal RNA; tRNA: Transfer RNA; tRNA gene: $\operatorname{trn} X$ (where $X$ is replaced by single letter amino acid code of the corresponding amino acid).

\section{Competing interests}

The authors declare that they have no competing interests.

\section{Authors' contributions}

TYC, KHC and ZC contributed to the conception and design of the study. FJL and $Y L$ performed the laboratory works of $A$. edulis, T. kelanang, $N$. glyptocercus and N. thermophilus. ZS and RL conducted the work on U. major. $Y L$ and LMT performed bioinformatics analyses of nucleotide and protein sequences. FJL and YL cooperated with the writing of the manuscript. ZC supervised the study and wrote the final draft of the manuscript. All authors read and approved the final manuscript.

\section{Acknowledgements}

Sincerely thanks are extended to H.H. Moh and V.C. Chong of the University of Malaya for kindly providing us some specimens of Thalassinia kelanang for the present study. We also thank Dr. MinXiao Wang of Institute of Oceanology, Chinese Academy of Sciences for his assistance in bioinformatics analyses. This work was supported by grants from the National Science Council, Taiwan to Tin-Yam Chan, National Natural Science Foundation of China 31172054 to Dr. Zhongli Sha, and Chinese National '863' Project (No. 2012AA10A409) and National Natural Science Foundation of China (41276165) to Dr. Zhaoxia Cui.

\section{Author details}

'Department of Life Sciences, National Cheng Kung University, Tainan, Taiwan. ${ }^{2}$ EMBL, Institute of Oceanology, Chinese Academy of Sciences, Qingdao 266071, China. ${ }^{3}$ Simon F. S. Li Marine Science Laboratory, School of Life Sciences, The Chinese University of Hong Kong, Shatin, Hong Kong. ${ }^{4}$ Institute of Marine Biology and Center of Excellence for Marine Bioenvironment and Biotechnology, National Taiwan Ocean University, Keelung, Taiwan.

Received: 12 June 2012 Accepted: 12 November 2012 Published: 16 November 2012

\section{References}

1. De Grave S, Deam Pentcheff N, Ahyong ST, Chan TY, Crandall KA, Dworschak PC, Felder DL, Feldmann RM, Fransen CHJM, Goulding LYD, et al: A classification of living and fossil genera of decapod crustaceans. The Raffles Bulletin of Zoology 2009, 21:1-109.

2. Tudge CC: Phylogeny of the Anomura (Decapoda, Crustacea): Spermatozoa and spermatophore morphological evidence. Contrib Zool 1997, 67(2):125-141.

3. Morrison CL, Harvey AW, Lavery S, Tieu K, Huang Y, Cunningham CW: Mitochondrial gene rearrangements confirm the parallel evolution of the crab-like form. P Roy Soc Lond B Bio 2002, 269(1489):345-350.

4. Tsang LM, Ma KY, Ahyong ST, Chan TY, Chu KH: Phylogeny of Decapoda using two nuclear protein-coding genes: origin and evolution of the Reptantia. Mol Phylogenet Evol 2008, 48(1):359-368.

5. Chu KH, Tsang LM, Ma KY, Chan TY, Ng PKL: Decapod phylogeny: what can protein-coding genes tell us. In Decapod Crustacean Phylogenetics. Edited by Martin JW, Crandall KA, Felder DL. New York: CRC Press; 2009:89-99.

6. Bracken HD, Toon A, Felder DL, Martin JW, Finley M, Rasmussen J, Palero F, Crandall KA: The decapod tree of life: compiling the data and moving toward a consensus of decapod evolution. Arthropod Systematics \& Phylogeny 2009, 67(1):99-116.

7. Bracken HD, De Grave S, Toon A, Felder DL, Crandall KA: Phylogenetic position, systematic status, and divergence time of the Procarididea (Crustacea: Decapoda). Zoologica Scripta 2010, 39(2):198-212.

8. Robles R, Tudge CC, Dworschak PC, Poore GCB, Felder DL: Molecular phylogeny of the Thalassinidea based on nuclear and mitochondrial genes. In Decapod Crustacean Phylogenetics. Edited by Martin JW, Crandall KA, Felder DL. New York: CRC Press; 2009:309-326.

9. Poore GCB: A phylogeny of the families of Thalassinidea (Crustacea: Decapoda) with keys to families and genera. Memoirs of the Museum of Victoria 1994, 54:79-120.
10. Scholtz G, Richter S: Phylogenetic systematics of the reptantian Decapoda (Crustacea, Malacostraca). Zool J Linn Soc-Lond 1995, 113(3):289-328.

11. Crandall KA, Harris DJ, Fetzner JW: The monophyletic origin of freshwater crayfish estimated from nuclear and mitochondrial DNA sequences. $P$ Roy Soc Lond B Bio 2000, 267(1453):1679-1686.

12. Schram FR: Phylogeny of decapods: moving towards a consensus. Hydrobiologia 2001, 449(1-3):1-20.

13. Martin JW, Davis GE: An updated classification of the recent crustacea. Natural History Museum of Los Angeles County: Science Series 2001, 39:1-124.

14. Dixon CJ, Ahyong ST, Schram FR: A new hypothesis of decapod phylogeny. Crustaceana 2003, 76:935-975

15. Ahyong ST, O'Meally D: Phylogeny of the Decapoda reptantia: Resolution using three molecular loci and morphology. Raffles B Zool 2004, 52(2):673-693.

16. Schram FR, Dixon CJ: Decapod phylogeny: addition of fossil evidence to a robust morphological cladistic data set. Bulletin of the Mizunami Fossil Museum 2004, 31:1-19.

17. Borradaile LA: On the classification of the Thalassinidea. The Annals and Magazine of Natural History, series 7 1903, 12:534-551.

18. Borradaile LA: On the classification of the decapod crustaceans. The Annals and Magazine of Natural History, series 7 1907, 19:457-486.

19. De Man JG: The Decapoda of the Siboga-expedition. Part 7. The Thalassinidae and Callianassidae collected by the Siboga-expedition with some remarks on the Laomediidae. Siboga Expéditie 1928, 39(A6):1-187.

20. Bouvier E-L: Décapodes marcheurs. Faune de France 1940, 37:1-407.

21. Zariquiey-Álvarez R: Crustáceos decápodos ibéricos. Investig Pesq 1968, 32:1-510.

22. Porter ML, Perez-Losada M, Crandall KA: Model-based multi-locus estimation of decapods phylogeny and divergence times. Mol Phylogenet Evol 2005, 37:355-369.

23. Boisselier-Dubayle MC, Bonillo C, Cruaud C, Couloux A, de Forges BR, Vidal N: The phylogenetic position of the 'living fossils' Neoglyphea and Laurentaeglyphea (Decapoda: Glypheidea). Comptes Rendus Biologies 2010, 333(10):755-759.

24. Holthuis LB: FAO species catalog. Vol. 13. Marine lobsters of the world. An annotated and illustrated catalogue of species of interest to fisheries known to date. In FAO Fisheries Synopsis. vol. 125. Rome: Food and Agriculture Organization of the United Nations; 1991:292.

25. Gurney R: Larvae of decapod crustacea. Part 5. Nephropsidea and thalassinidea. Discovery Reports 1938, 17:291-344.

26. Gurney R: Larvae of decapod Crustacea. London: Ray Society; 1942.

27. De Saint Laurent M: Versune nouvelle classification des Crustaces Decapodes Reptantia. Bulletin de I'Office National des Peches Republique Tunisienne, Ministere de UAgriculture 1979, 3:15-31.

28. De Saint Laurent M: Sur la classification et la phylogenie des Thalassinides: definitions de la superfamille des Axioidea, de la sousfamille des Thomassiniinae et de deux genres nouveaux (Crustacea Decapoda). C R Hebd Acad Sci 1979, 288:1395-1397.

29. Tudge C: Ultrastructure and phylogeny of the spermatozoa of the infraorders Thalassinidea and Anomura (Decapoda, Crustacea). In Advances in Spermatozoal Phylogeny and Taxonomy. Edited by Jamieson BGM, Ausio J, Justin JL. Paris: Mémoires du Muséum National d'Histoire Naturelle; 1995:251-263. vol. 166.

30. Tsang LM, Lin FJ, Chu KH, Chan TY: Phylogeny of Thalassinidea (Crustacea, Decapoda) inferred from three rDNA sequences: implications for morphological evolution and superfamily classification. J Zool Syst Evol Res 2008, 46(3):216-223.

31. Harrison MK, Crespi BJ: Phylogenetics of Cancer crabs (Crustacea: Decapoda: Brachyura). Mol Phylogenet Evol 1999, 12(2):186-199.

32. Ptacek MB, Sarver SK, Childress MJ, Herrnkind WF: Molecular phylogeny of the spiny lobster genus Panulirus (Decapoda: Palinuridae). Mar Freshwater Res 2001, 52(8):1037-1047.

33. Munasinghe DHN, Burridge $C P$, Austin CM: Molecular phylogeny of the spiny lobster genus Panulirus (Decapoda: Palinuridae). Biol J Linn Soc 2004, 81(4):553-563.

34. Shih HT, Ng PKL, Schubart CD, Chang HW: Phylogeny and phylogeography of the genus Geothelphusa (Crustacea: Decapoda, Brachyura, Potamidae) in southwestern Taiwan based on two mitochondrial genes. Zool Sci 2007, 24(1):57-66.

35. Roe AD, Sperling FAH: Patterns of evolution of mitochondrial cytochrome c oxidase I and II DNA and implications for DNA barcoding. Mol Phylogenet Evol 2007, 44(1):325-345. 
36. Boore JL: Animal mitochondrial genomes. Nucleic Acids Res 1999, 27(8):1767-1780.

37. Kilpert F, Podsiadlowski L: The complete mitochondrial genome of the common sea slater, Ligia oceanica (Crustacea, Isopoda) bears a novel gene order and unusual control region features. BMC Genomics 2006, 7:241-258.

38. Gissi C, lannelli F, Pesole G: Evolution of the mitochondrial genome of Metazoa as exemplified by comparison of congeneric species. Heredity 2008, 101(4):301-320.

39. Wilson AC, Cann RL, Carr SM, George M, Gyllensten UB, Helmbychowski KM, Higuchi RG, Palumbi SR, Prager EM, Sage RD, et al: Mitochondrial DNA and two perspectives on evolutionary genetics. Biol J Linn Soc 1985, 26:375-400.

40. Boore JL, Collins TM, Stanton D, Daehler LL, Brown WM: Deducing the pattern of arthropod phylogeny from mitochondrial DNA rearrangements. Nature 1995, 376(6536):163-165.

41. Avise JC: Phylogeography: The history and formation of species. Cambridge, MA: Harvard Univ Press; 2000.

42. Boore JL, Macey JR, Medina M: Sequencing and comparing whole mitochondrial genomes of animals. Molecular Evolution: Producing the Biochemical Data, Part B 2005, 395:311-348.

43. Cui ZX, Liu YA, Li CP, Chu KH: Species delineation in Pampus (Perciformes) and the phylogenetic status of the Stromateoidei based on mitogenomics. Mol Biol Rep 2011, 38(2):1103-1114.

44. Yamauchi MM, Miya MU, Machida RJ, Nishida M: PCR-based approach for sequencing mitochondrial genomes of decapod crustaceans, with a practical example from kuruma prawn (Marsupenaeus japonicus). Mar Biotechnol 2004, 6(5):419-429.

45. Elson $\mathrm{L}$, Lightowlers RN: Mitochondrial DNA clonality in the dock: can surveillance swing the case? Trends Genet 2006, 22(11):603-607.

46. Qian G, Zhao Q, Wang AN, Zhu LIN, Zhou K, Sun H: Two new decapod (Crustacea, Malacostraca) complete mitochondrial genomes: bearings on the phylogenetic relationships within the Decapoda. Zool J Linn Soc-Lond 2011, 162(3):471-481

47. Boore JL, Brown WM: Big trees from little genomes: mitochondrial gene order as a phylogenetic tool. Curr Opin Genet Dev 1998, 8(6):668-674.

48. Dowton M: Relationships among the cyclostome braconid (Hymenoptera: Braconidae) subfamilies inferred from a mitochondrial tRNA gene rearrangement. Mol Phylogenet Evol 1999, 11(2):283-287.

49. Simon C, Buckley TR, Frati F, Stewart JB, Beckenbach AT: Incorporating molecular evolution into phylogenetic analysis, and a new compilation of conserved polymerase chain reaction primers for animal mitochondrial DNA. Annu Rev Ecol Evol S 2006, 37:545-579.

50. Kim S, Kim J, Choi HG, Park JK, Min GS: Complete mitochondrial genome of the northern mauxia shrimp Acetes chinensis (Decapoda, Dendrobranchiata, Sergestoidae). Mitochondrial DNA 2012, 23(1):28-30.

51. Kim S, Park MH, Jung JH, Ahn DH, Sultana T, Park JK, Choi HG, Min GS: The mitochondrial genomes of Cambaroides similis and Procambarus clarkii (Decapoda: Astacidea: Cambaridae): the phylogenetic implications for Reptantia. Zoologica Scripta 2012, 41(3):281-292.

52. Shi H, Liu R, Sha Z, Ma J: Complete mitochondrial DNA sequence of Stenopus hispidus (Crustacea: Decapoda: Stenopodidea) and a novel tRNA gene cluster. Marine Genomics 2012, 6:7-15.

53. Kim S, Kim T, Choi HG, Park JK, Ahn DH, Min GS: The complete mitochondrial genome of the Japanese mud shrimp Upogebia major (Crustacea, Decapoda). Mitochondrial DNA 2011, 22(4):94-96.

54. Wolstenholme DR: Animal mitochondrial DNA: Structure and Evolution. Int Rev Cytol 1992, 141:173-216.

55. Boore JL, Lavrov DV, Brown WM: Gene translocation links insects and crustaceans. Nature 1998, 392(6677):667-668.

56. Sun H, Zhou K, Song D: Mitochondrial genome of the Chinese mitten crab Eriocheir japonica sinenesis (Brachyura: Thoracotremata: Grapsoidea) reveals a novel gene order and two target regions of gene rearrangements. Gene 2005, 349:207-217.

57. Yang JS, Nagasawa H, Fujiwara Y, Tsuchida S, Yang WJ: The complete mitochondrial genome sequence of the hydrothermal vent galatheid crab Shinkaia crosnieri (Crustacea: Decapoda: Anomura): a novel arrangement and incomplete tRNA suite. BMC Genomics 2008, 9:257.

58. Ki JS, Dahms HU, Hwang JS, Lee JS: The complete mitogenome of the hydrothermal vent crab Xenograpsus testudinatus (Decapoda, Brachyura) and comparison with brachyuran crabs. Comp Biochem Physiol Part D Genomics Proteomics 2009, 4(4):290-299.
59. Liu Y, Cui Z: The complete mitochondrial genome of the mantid shrimp Oratosquilla oratoria (Crustacea: Malacostraca: Stomatopoda): Novel noncoding regions features and phylogenetic implications of the Stomatopoda. Comp Biochem Physiol Part D Genomics Proteomics 2010, 5(3):190-198.

60. Cook CE, Yue QY, Akam M: Mitochondrial genomes suggest that hexapods and crustaceans are mutually paraphyletic. Proceedings of the Royal Society B-Biological Sciences 2005, 272(1569):1295-1304.

61. Yamauchi MM, Miya MU, Nishida M: Complete mitochondrial DNA sequence of the Japanese spiny lobster, Panulirus japonicus (Crustacea: Decapoda). Gene 2002, 295(1):89-96.

62. Liu Y, Cui Z: Complete mitochondrial genome of the Chinese spiny lobster Panulirus stimpsoni (Crustacea: Decapoda): genome characterization and phylogenetic considerations. Mol Biol Rep 2011 38(1):403-410.

63. Boore JL: The duplication/random loss model for gene rearrangement exemplified by mitochondrial genomes of deuterostome animals. In Comparative genomics, computational biology series Volume 1. Edited by Sankoff D, Nadeau J. Kluwer, Dordrecht: Academic Publishers; 2000:133-147.

64. Lavrov DV, Boore $J$, Brown WM: Complete mtDNA sequences of two millipedes suggest a new model for mitochondrial gene rearrangements: Duplication and nonrandom loss. Mol Biol Evol 2002, 19(2):163-169.

65. Lunt DH, Hyman BC: Animal mitochondrial DNA recombination. Nature 1997, 387(6630):247.

66. Shao RF, Barker SC: The highly rearranged mitochondrial genome of the plague thrips, Thrips imaginis (Insecta: thysanoptera): Convergence of two novel gene boundaries and an extraordinary arrangement of rRNA genes. Mol Biol Evol 2003, 20(3):362-370.

67. Wang MX, Sun S, Li CL, Shen X: Distinctive mitochondrial genome of Calanoid copepod Calanus sinicus with multiple large non-coding regions and reshuffled gene order: Useful molecular markers for phylogenetic and population studies. BMC Genomics 2011, 12:73.

68. Higgs PG, Jameson D, Jow H, Rattray M: The evolution of tRNA-Leu genes in animal mitochondrial genomes. J Mol Evol 2003, 57(4):435-445.

69. Krebes L, Bastrop R: The mitogenome of Gammarus duebeni (Crustacea Amphipoda): A new gene order and non-neutral sequence evolution of tandem repeats in the control region. Comp Biochem Phys D 2012, 7(2):201-211.

70. Ito A, Aoki MN, Yokobori S, Wada H: The complete mitochondrial genome of Caprella scaura (Crustacea, Amphipoda, Caprellidea), with emphasis on the unique gene order pattern and duplicated control region. Mitochondrial DNA 2010, 21(5):183-190.

71. Segawa RD, Aotsuka T: The mitochondrial genome of the Japanese freshwater crab, Geothelphusa dehaani (Crustacea: Brachyura): Evidence for its evolution via gene duplication. Gene 2005, 355:28-39.

72. Tavares C, Serejo C, Martin JW: A preliminary phylogenetic anaylsis of the Dendrobranchiata based on morphological characters. In Decapod Crustacean Phylogenetics. Edited by Martin JW, Crandall KA, Felder DL, Boca R. London, New York: CRC Press, Taylor \& Francis Group; 2009:261-279.

73. Tsang LM, Chan TY, Ahyong ST, Chu KH: Hermit to king, or hermit to all: multiple transitions to crab-like forms from hermit crab ancestors. Syst Biol 2011, 60(5):616-629.

74. Folmer O, Black M, Hoeh W, Lutz R, Vrijenhoek R: DNA primers for amplification of mitochondrial cytochrome c oxidase subunit I from diverse metazoan invertebrates. Mol Mar Biol Biotechnol 1994, 3(5):294-299.

75. Lavrov DV, Brown WM, Boore JL: Phylogenetic position of the Pentastomida and (pan)crustacean relationships. P Roy Soc Lond B Bio 2004, 271(1538):537-544

76. Schubart CD, Neigel JE, Felder DL: Use of the mitochondrial 16S rRNA gene for phylogenetic and population studies of Crustacea. Crustacean Iss 2000, 12:817-830.

77. Boore JL, Brown WM: Mitochondrial genomes of Galathealinum, Helobdella, and Platynereis: Sequence and gene arrangement comparisons indicate that Pogonophora is not a phylum and Annelida and Arthropoda are not sister taxa. Mol Biol Evol 2000, 17(1):87-106.

78. Hunter RL, Webb MS, Iliffe TM, Bremer JRA: Phylogeny and historical biogeography of the cave-adapted shrimp genus Typhlatya (Atyidae) in the Caribbean Sea and western Atlantic. J Biogeogr 2008, 35(1):65-75.

79. Podsiadlowski L, Bartolomaeus T: Organization of the mitochondrial genome of mantis shrimp Pseudosquilla ciliata (Crustacea: Stomatopoda). Mar Biotechnol 2005, 7(6):618-624. 
80. Peregrino-Uriarte AB, Varela-Romero A, Muhlia-Almazan A, Anduro-Corona I, Vega-Heredia S, Gutierrez-Millan LE, De la Rosa-Velez J, Yepiz-Plascencia G: The complete mitochondrial genomes of the yellowleg shrimp Farfantepenaeus californiensis and the blue shrimp Litopenaeus stylirostris (Crustacea: Decapoda). Comp Biochem Physiol Part D Genomics Proteomics 2009, 4(1):45-53.

81. Miya M, Pietsch TW, Orr JW, Arnold RJ, Satoh TP, Shedlock AM, Ho HC, Shimazaki M, Yabe M, Nishida M: Evolutionary history of anglerfishes (Teleostei: Lophiiformes): a mitogenomic perspective. BMC Evol Biol 2010, 10:58.

82. Ewing B, Green P: Base-calling of automated sequencer traces using phred. II. Error probabilities. Genome Res 1998, 8(3):186-194.

83. Ewing B, Hillier L, Wendl MC, Green P: Base-calling of automated sequencer traces using phred. I. Accuracy assessment. Genome Res 1998 8(3):175-185.

84. Gordon D, Abajian C, Green P: Consed: a graphical tool for sequence finishing. Genome Res 1998, 8:195-202.

85. Wyman SK, Jansen RK, Boore JL: Automatic annotation of organellar genomes with DOGMA. Bioinformatics 2004, 20(17):3252-3255.

86. Lowe TM, Eddy SR: tRNAscan-SE: A program for improved detection of transfer RNA genes in genomic sequence. Nucleic Acids Res 1997. 25(5):955-964

87. Lupi R, de Meo PD, Picardi E, D'Antonio M, Paoletti D, Castrignano T, Pesole G, Gissi C: MitoZoa: A curated mitochondrial genome database of metazoans for comparative genomics studies. Mitochondrion 2010, 10(2):192-199.

88. Bernt M, Merkle D, Ramsch K, Fritzsch G, Perseke M, Bernhard D, Schlegel M, Stadler PF, Middendorf M: CREx: inferring genomic rearrangements based on common intervals. Bioinformatics 2007, 23(21):2957-2958.

89. Thompson JD, Gibson TJ, Plewniak F, Jeanmougin F, Higgins DG: The ClustalX windows interface flexible strategies for multiple sequence alignment aided by quality analysis tools. Nucleic Acids Res 1997, 25:4876-4882

90. Xia XH, Xie Z, Salemi M, Chen L, Wang Y: An index of substitution saturation and its application. Mol Phylogenet Evol 2003, 26(1):1-7.

91. Xia X, Xie Z: DAMBE software package for data analysis in molecular biology and evolution. J Hered 2001, 92:371-373.

92. Lartillot N, Lepage T, Blanquart S: PhyloBayes 3: a Bayesian software package for phylogenetic reconstruction and molecular dating. Bioinformatics 2009, 25(17):2286-2288.

93. Stamatakis A: RAxML-VI-HPC: maximum likelihood-based phylogenetic analyses with thousands of taxa and mixed models. Bioinformatics 2006, 22(21):2688-2690.

94. Posada D: jModelTest: phylogenetic model averaging. Mol Biol Evol 2008 , 25(7):1253-1256.

95. Abascal F, Zardoya R, Posada D: ProtTest: selection of best-fit models of protein evolution. Bioinformatics 2005, 21(9):2104-2105.

96. Lartillot $\mathrm{N}$, Philippe $\mathrm{H}$ : A bayesian mixture model for across-site heterogeneities in the amino-acid replacement process. Mol Biol Evol 2004, 21(6):1095-1109.

97. Lartillot N, Brinkmann H, Philippe H: Suppression of long-branch attraction artefacts in the animal phylogeny using a site-heterogeneous model. BMC Evol Biol 2007, 7(1):S4

98. Shimodaira H, Hasegawa M: CONSEL: for assessing the confidence of phylogenetic tree selection. Bioinformatics 2001, 17(12):1246-1247.

99. Shimodaira $H$ : An approximately unbiased test of phylogenetic tree selection. Syst Biol 2002, 51(3):492-508.

doi:10.1186/1471-2164-13-631

Cite this article as: Lin et al:: Evolution and phylogeny of the mud shrimps (Crustacea: Decapoda) revealed from complete mitochondrial genomes. BMC Genomics 2012 13:631.

\section{Submit your next manuscript to BioMed Central and take full advantage of:}

- Convenient online submission

- Thorough peer review

- No space constraints or color figure charges

- Immediate publication on acceptance

- Inclusion in PubMed, CAS, Scopus and Google Scholar

- Research which is freely available for redistribution

Submit your manuscript at www.biomedcentral.com/submit
C Biomed Central 